\title{
International Leadership After the Demise of the Last Superpower: System Structure and Stewardship
}

\author{
Ole Wrever $^{1}$ (D)
}

Received: 22 August 2017/Accepted: 20 September 2017/Published online: 13 November 2017

(C) Fudan University and Springer Nature Singapore Pte Ltd. 2017

\begin{abstract}
Who will take care of what global challenges-and why not? Does the international system have an emerging pattern of leadership, or does system structure either preclude leadership as such or prevent prediction of any systematic form hereof? It is widely agreed among scholars and practitioners alike that the 'structure' of the international system in some broad sense, and most often with an emphasis on the distribution of power (polarity), circumscribes the conditions for cooperation and joint action. So this paper will first discuss the proper designation of the emerging structure, then what implications this has for conflict and cooperation and thirdly on this basis: who will take what kinds of leadership roles especially in relation to the management and confrontation of global challenges and dangers? A number of diagnoses of the current and emerging structure appear to be largely in synch, however placing their emphasis on slightly different points or doing so differently: multipolarity, no one's world, a world without superpowers, G-Zero, New World Disorder, etc. The first part of the paper, compares and systematices these different conceptions of system structure. The paper argues why seemingly minor differences in conception might make a substantial difference as to expectations and interpretations of patterns of cooperation and conflict in the system. The emerging structure is one of no superpowers and with the main great powers nested in different regions. This points towards a pattern of conflict and cooperation that is basically de-centered-not a focused competition for world power or for leadership as an aim in its own right. Leadership will therefore vary from issue-area to issue-area and sometimes case to case. Does this mean that we just have to wait and see-and despair? Or is it possible, at least to some limited
\end{abstract}

Ole Wæver

ow@ifs.ku.dk

1 Department of Political Science, Centre for Resolution of International Conflicts, University of Copenhagen, Øster Farimagsgade 5, 1353 Copenhagen K, Denmark 
extent, to predict when what powers will step forward and thereby who will be the main players in what kind of constellations in different domains?

Keywords International leadership - International system structure · Polarity · Regional security complex theory · Great powers

\section{Introduction}

Who will take care of what global challenges - and why not? Does the international system have an emerging pattern of leadership, or does system structure either preclude leadership as such or prevent prediction of any systematic form hereof?

It is widely agreed among scholars and practitioners alike that the 'structure' of the international system in some broad sense-and most often with an emphasis on the distribution of power ('polarity') — circumscribes the conditions for cooperation and joint action. So this paper will first discuss the proper designation of the emerging structure, then what implications this has for conflict and cooperation and thirdly on this basis: who will take what kinds of leadership roles especially in relation to the management and confrontation of global challenges and dangers?

A number of diagnoses of the current and emerging structure appear to be largely in synch, however placing their emphasis on slightly different points or doing so differently: multipolarity, no one's world, a world without superpowers, G-Zero, New World Disorder, a world in disarray_and in the sphere of commentary: Trump as trump in any explanation. The first part of the paper, compares and systematices these different conceptions of system structure. The paper argues why seemingly minor differences in conception might make a substantial difference as to expectations and interpretations of patterns of cooperation and conflict in the system. The emerging structure is, it is argued here, one of no superpowers and with the main great powers nested in different regions. This points towards a pattern of conflict and cooperation that is basically de-centered-not a focused competition for world power or for leadership as an aim in its own right. Leadership will therefore vary from issue-area to issue-area and sometimes case to case. Does this mean that we just have to wait and see-and despair? Or is it possible, at least to some limited extent, to predict when what powers will step forward and thereby who will be the main players in what kind of constellations in different domains?

An important distinction that helps to a realistic conception of future global leadership is to distinguish between cooperation driven by security of a new kind versus cooperation for mutual gains in a more 'optimistic' sense. This roughly realist argument serves to severe the problematic link between 'cooperation' and 'niceness'. Leadership in orchestrating cooperation can be competitive and motivated by inter-state rivalry; or it can aim at shared-fate issues, but the latter will mostly be able to generate leadership in the emerging system when those shared-fate issues are thoroughly securitized and/or the leadership has inherent value for the power in case as a means to project a useful role identity. In a world of many great power more widely dispersed in a decentered global system, it becomes 
more important to trace the motivating push for each power to opt in on any given issue, because the system does not have an integrated power structure at the global level with sufficient force to pull states in 'from above' so to say.

\section{In Defense of Neorealism (Almost)—or: Who Wants Structure?}

Before I engage in a discussion of the advantages and disadvantages of various possible designations of the current system structure, it might be reasonable to ask: why do we want something like a concept of global structure and what should we reasonably ask of such a conception?

This introductory article is quite 'traditionalist' relative both to the general field of IR today and (less importantly) to what some might expect from the current author. There are four reasons for this (in addition to the fact that I actually think about the world like this, sometimes):

1. When change is deep and fundamental, it is particularly important to get a clear sense of how deep, i.e. to move down towards the most constant layers constitutive of 'international relations' to see what might be continuous and what is not.

2. There is a risk in the current situation of moving too quickly to new generalizations, e.g. to see China-EU as the natural leaders of the world based on the Paris-Climate-case. It is important to clarify constraints and thereby contextualize and condition a given case and thus get a realistic picture of what other cases will follow the same trajectory, and which ones are likely not to.

3. All kinds of critical scholarship de facto writes up against a realist baseline story. Currently, the neo-realists do not get their own analysis right, so for critical scholars it is necessary first to do the realists' job and then add the critical counter pose.

4. This special issue contains several articles by critical scholars who complement this analysis elegantly.

The point here is not that power equals leadership and that an analysis of power in itself constitutes an answer about future leadership - it might even be that the gap between the two is growing (Acharya 2014). The rationale for updating the power analysis is that it is a productive first step towards explaining and predicting global leadership. The relationship is not necessarily linear, so that the most powerful state is also necessarily the one that leads most. Systems have existed historically where a power has been dominant without leading or a state from a lower 'rank' have had particularly good reasons to take upon itself leadership roles. Still, these particular roles were in important ways conditioned by the power structure at the time.

The next question is then, what it means to talk structure?

Structure? Basically, in the social sciences 'structure' is a term we use for anything that is more stable than something else-and simultaneously captures features of the overall organization of the larger social system and has effects. Nothing is a 'structure' in itself and with no purpose (cf. ordinary language 
philosophy). It only makes sense to talk about 'structure' in relation to explanations - that something has the status of structure in an explanatory setting. ${ }^{1}$ To say that something is a 'structural' explanation implies it has a relative stability over time that is larger than that which it explains. In addition, a structure is somehow anchored at the systemic level; we typically do not designate something as 'structure' if it is a repetitive feature anchored at the individual level. Thus, to talk about 'structure' means to look at the level of system for relatively stable features that can be attributed causality and preferably have something organizational or pattern-like to them.

Not all systemic features are structural. There are non-structural systemic features in addition to structural systemic factors. Whether this terminology is totally logical or it is just convention might be a matter of debate, but in International Relations (IR) it has become relatively well-established that international structure' first of all means the power structure (polarity) and 'systemic non-structural features' can be other also very powerful factors like the general level of technological development, interdependence and density of institutional infrastructure (Ruggie 1983; Wæver 1992; Buzan et al. 1993; Deudney 2006). These are factors that characterise the system in general and shape international politics in the direction 'system-to-behavior'; yet they are not 'structural' because they are not about the distribution of power. For all the credit we owe Kenneth Waltz for pointing our attention at the structure of the international system (Waltz 1979), he made the one big mistake of conflating systemic and structural, i.e. assuming that explanations can only be anchored at the systemic level if they are about the (political) structure of the system, i.e. the distribution of power. He violated that principle himself by pointing to the importance of nuclear weapons as impacting system dynamics, i.e. a non-structural systemic factor with huge impact even on security dynamics. Some of these systemic non-structural factors have a cumulative and largely linear nature (except in the case of major human disaster and breakdown), i.e. historically the 'interaction capacity' of human collectives have grown and the number of humans as well, with the dual effects of increasing density of human interactions and shifting downwards the potential for destruction to gradually smaller actors, which in turn puts pressure on social organization calling

\footnotetext{
${ }^{1}$ Niklas Luhmann argues convincingly in Die Wissenschaft der Gesellschaft - the volume in his series on society's various 'systems' that deals with 'science' - that the deep code of science is 'true/false' (Luhmann 1990). And (even more controversially; but still true) that it is about explanation. Now, we will have most of my post-structuralist and constructivist friends up in arms arguing that social science can certainly be critical and look at 'constitutive' dynamics, not causal ones. That is true(!). But still, it is all tied into a social system (science) that somehow is anchored in the rationale of being able to supply to society what causal explanations are true, what are false. Even a social theorist as anti-a priori as Bruno Latour has recently - partly under the pressure from the global climate crisis, partly as a response to internal tensions in his own theory - allowed for a kind of functional differentiation of different social systems where science is the system that operates on the basis of the locutionary speech act of pronouncing on how it actually is (Latour 2013). Surely, we therefore needs all kinds of sophisticated discussions of what is meant by explanation and understanding and reality; but those sophistications are generated by a basic, primitive agenda of 'knowing reality'. And it is the complete multi-layered conversation - the traditionalists as well as the critical voices and the meta-theoreticians - that all in combination produce an edifice that generates a particular form of insight and understanding that is peculiar to the academic institution.
} 
for structures able to constrain destruction. ${ }^{2}$ While these general societal forces are clearly important, their effects are under normal conditions channeled through the political set-up at a given time, i.e. the challenges are certainly real, but the way they will be met are (over)determined by the constellation of powers. Therefore, it is important to beware of the functionalist fallacy of drawing direct conclusions from problems to solutions, from the 'rationality' of facing up to challenges to the actual political possibility of doing so.

In the present paper, I am treating this 'liberal factor' as a slow pressure that might occasionally break through, especially when attaining security stature. Whenever we get more interdependent and all that, it would be very nice if we could match this with improved cooperation. Most often this is not going to happen, because we are looking here at international relations. But ultimately, sometimes, in the long run, the cumulative effect of who can do what to whom on what scale does challenge structure (a good old Marxist argument, of course). More concretely, the way this primarily manifests itself is through collective, existential dangers, i.e. when a collective threat is securitized on par with or above the potential state-tostate security dynamics.

Similar to the way structure most of the time channels and constrains interaction capacity, events and interactions often have causes outside of the power structure, but ultimately are routed by the constellation of great powers. There is consequently a similar subdued potentiality to specific issues on the international agenda and their ensuing 'conflict constellations': when policy-makers analyze 'the situation', they tend to emphasize the conflicts of the day. Naturally, when 'the West' and various 'islamist' actors are engaged for more than a decade in a complex transnational conflict, it is hard not to project this into the future and to assume that it somehow is its own cause, i.e. that the nature of the 'problem' has determined the political constellation. Actually, it is the other way around: the overall power political constellation did a lot to determine how concrete challenges relating to terrorism and religion were countered. It was because the US was at the time in a situation of 'almost unipolarity', that it was both possible and attractive to mobilize a 'global war on terrorism' (Buzan and Wæver 2009). The generalized version of this observation is: yes, we need to follow the rise and fall of various conflict constellations and focal issues, but they certainly do not on their own determine who ends up fighting whom. It is on the basis of the constellation of powers at a given point in time that a particular issue gets politicized and securitized. There is a feedback from such conflicts on the underlying configuration of powers, but it is usually better to analyze the underlying power constellation first and ask how the process might re-configure this constellation, rather than starting from the politics of the day and project it into the future. The argument here is not that specific conflicts are always the product of power dynamics - very often unexpected issues arise 'out of nowhere'-but the response will to a large extent be constrained by the

\footnotetext{
${ }^{2}$ In the intense but by now probably largely forgotten (?) debate that evolved in one particular trail following Waltz's Theory, this was often phrased as a contrast between relative power (polarity, distribution of power) and absolute power (we can all 'do' more than we could 1000 years ago due basically the development of technologies, including social and industrial technologies); cf Ruggie 1983; Wæver 1992; Buzan et al. 1993; Deudney 2006. For an important recent revisiting, see Tang 2013.
} 
constellation of powers. This is why it is important to have a conception of the power structure.

As scholars of international relations, we are collectively committed to offering an interpretation of world politics. Personally, as someone who has been involved at various stages with the more 'critical' wing of IR and security studies, I am naturally inclined to make room for the non-traditional in relation to both the what and the how, i.e. the possibility that other factors than power, arms and states win out, and also under-determined processes make the way things happen matter, i.e. 'underlying' interests get reshaped by processes (Wendt 1992). From my own garden, one version of an anti-structuralist argument could build on a combination of securitization theory and conflict analysis and argue that patterns of conflict and securitization firstly can be launched on the basis of any kind of issue, and secondly are self-reinforcing, and therefore political conflict formations can emerge and keep going for long periods (Bramsen et al. 2018). It is important to keep open this possibility, but exactly because of its unpredictable and self-installing nature, this kind of development cannot form base-line projections. Both analytical and political reasons suggest looking at power before process. Analytically, there simply is a scarcity of 'big picture' analyses from critical and radically constructivist scholars-lots of clever methods to analyze developments under way, but less for projecting trends, triggers and forces. ${ }^{3}$ Politically, the reasoning echoes the classical realist insight that self-delusion is so easy that we should beware of how our analysis is nested in the power structure (Niebuhr 1932; Kissinger 1957).

When trying to capture the 'big picture', it makes a lot of sense to be a 'traditionalist' and proceed in the sequence of (1) power structure, (2) political constellations formed by actors in relation to issues, and (3) cumulative pressure from underlying socio-technological dynamics. ${ }^{4}$ In the present context, the second layer-events/constellations-will appear in several of the articles that follow, but not in this chapter as such.

However, one more bridge from power structure to leadership will be employed. Attempts to lead internationally do come forth also when it squares with national identity projection and 'polity consolidation' to project a certain international project. This identity-polity argument can be illustrated by the EU and the environment: why did the EU latch on first to environmentalism in general and later climate policy in particular? Of course because we are good global citizens, but not only: it can be argued convincingly that the EU opted for the position of being a frontrunner on the climate because this role built a case for a stronger EU and thus it

\footnotetext{
${ }^{3}$ Obviously, the main exception here is IPE, International Political Economy, which does offer such general analyses including projections into the future..

4 There is ultimately no neutral way to relate these three dimensions, because they operate on three different planes of time: structure is circular, interaction capacity linear and process is pointwise (or more inclusively: repetitive, cumulative and specific). Any text will by its choice of narrative structure privilege one or the other of these formats. However, there are pragmatic (as well as IR conventional) reasons to use 'structure' as the integrative element: it contains a certain space of variation, which captures much of international history and both of the other formats speak to it: when do specific, emergent constellations generate dynamism enough to impact the structure, and when does underlying, cumulative change become enough to overwhelm the structure? A possible dictum is therefore: study structure, prepare for events, look out for interaction capacity.
} 
reinforced 'polity building' for the EU (Jachtenfuchs 1994), similar to the way that earlier state-building projects had latched on to various agendas that served to build the state in case, e.g. with a Danish angle: how Prussia picked a war with little Denmark to build Germany. This is an important lesson for contemporary analysis of 'global challenges', that states (or semi-states like the EU) most likely take up these tasks — or at least only manage to sustain a commitment-if the involvement also serves to strengthen the actorhood of the polity in case. (Wæver 2011).

All in all, three potential drivers for leadership have been introduced. First, the power structure can actually stimulate leadership - this is the case if security-driven rivalry calls for competitive leadership as clearly was the case during the bipolar cold war period, during parts of the (almost) unipolar post-war period and often also during multipolarity, but as argued below, the current structure does not in itself constitute consistent security motivations for leadership, because it does not have a rivalry over polarity as such. Secondly, shared-fate issues can form the basis for leadership, but if costly as this usually is, such leadership is most likely if the issues are securitized to a very high degree. Thirdly, in a system with little system level pull, it is important to look for dynamics behind leadership that are more domestically driven and the most important (and most systematically theorizable) of these is the case where leadership suits the design and consolidation of a polity project.

Thus, this article is semi-traditionalist. Maybe, it can be argued generally that the more dramatic changes are, the more we need to look for underlying structural constants and patterns, and especially we need to be extremely attentive to the relationship between continuity and change, constant dynamics and novel factors.

This means amongst other things that it is important to respect the fundamental analytical difference between polarity and polarization (Goldmann 1974), i.e. the distribution of power is one thing and another is the pattern formed by powers. For instance, if there are four great powers in a system, it is multipolar-and if they group together two and two, the system becomes bi-polarized, but it is still multipolar. ${ }^{5}$ Structure is distinct from behavior.

Who then are the great powers? Isn't it meaningless to make a statement like the one I did three lines ago about keeping a concept of polarity distinct from polarization, unless one has an objective measure of 'power' and thereby the ability to rank states in the international system quantitatively on a single scale? No, as it is often the case, the discipline is mixing up different senses of 'social construction', conflating ontological and epistemological aspects of this. It is important to keep a basic distinction between the existence of something like power and the ability to measure it objectively and independently. The necessary assumption here is that

\footnotetext{
5 Similarly, it is terminologically confusing when a Yan Xuetong article (originally from Global Times 2011) is reprinted with the headline "For a New Bipolarity: China and Russia vs. America"(Xuetong 2013). The simplification is not surprising given the editorial concerns of a journal for a wider audience. 'Bipolarized tripolarity' is probably not headline language. What Yan Xuetong writes is actually less problematic: China "will be unable to shift the world from unipolarity to bipolarity unless it forms an alliance with Russia". The power structure including its polarity is not a passive product of underlying 'sources' of power (like technology, demographics, economy, cultural productivity etc), policies and practices impact power as well, not least through factors like reputation and expectations (Morgenthau 1948). This is compatible especially with Yan Xuetong's version of realism (Yan 2011; Yan et al. 2011).
} 
there is such a thing like power, and that there are consequently powers-sometimes the actual state of power will only be revealed in hindsight (e.g. by the outcome of wars or other contests of force), sometimes what matters is the social reality of power and thus the power ascribed by other actors. Neither of these two depend on the ability of analysts to measure power, nor do they force us to abandon the concept of power.

\section{What is the Structure of the International System Today?}

After this brief justification for looking for and looking at the structure of the international system in terms of powers and polarity, the next question is of course if we can find it. Is it possible to pin down the current structure of the international system?

To do this, we have to remind ourselves that the simple but in some sense surprising point of polarity is that the number of powers in the system matters greatly. Polarity analysis is not an exploration of whether the system is shaped by rivalry and balance of power, but how it is. Nor is it about who the powers are, but how many. Especially the latter is different from the policy view held even by those politicians who declare themselves wedded to a realist and power political approach - they will typically be arguing about the big difference during the Cold War following from the Soviet Union or the US being number one, and today whether China becomes the most powerful or the US; and in Europe whether the EU is a super power or not. Politicians and commentators usually worry about who will be the powers, not how many there will be. The point of polarity analysis, however, is that the general patterns and dynamics are different in bipolarity and multipolarity-bipolarity being relatively rigid, predictable and less prone to misunderstandings, while multipolarity is more fluid both in the good sense that things can be done and in the bad that risky maneuvers make sense and misunderstandings are more likely (Waltz 1979). According to Ken Waltz, who first made this argument in full clarity, the other options- unipolarity and tripolarityare unstable and not relevant as structural options. When, however, the world appeared to be in a situation of at least 'near unipolarity' after the end of the Cold War, a number of theorists tried to speculate about both the dynamics of a unipolar system and factors that might make it viable against the orthodox Waltzian view that a balance of power system naturally cannot be that unbalanced. Today, we no longer need to go into these discussions in detail, since we can probably agree now on at least one of three possible interpretations: (1) the system really never was as unipolar as assumed, (2) it is no longer unipolar, or (3) it is heading out of unipolarity and discussions of the emerging system has to capture what comes after unipolarity.

The interpretation that Barry Buzan and I presented in 2003 in the book "Regions and powers" (Buzan and Wæver 2003) was that the structure already then was in an in-between situation between unipolarity and multipolarity of a particular nature that could only be captured by taking into account that security in the world mainly operates at the regional level. This lead to an interpretation involving both super 
powers and great powers. The formula was " $1+4+$ regions" - one super power, four great powers and a powerful regional level with at the time 11 regional security complexes.

The regional level is of dual importance in getting the global structure right. First, it is important that most states in the world are concerned more about their region than about 'global security' - most of their security concerns stem from other actors in their own region-and therefore much of security in the world comes in clusters. One region in the world (say Latin America) might be on a positive trend, while another (say Middle East) is on a negative-and one might be heading towards nonstate actors and post-traditional security issues, while another is centred on states and traditional security. Also, most regions are structured from the inside out: their main security problems stem from relations among actors in the region, and attempts to reshape and transform a region from the outside often prove more difficult than assumed. This was already under-estimated during the Cold War where security studies tended (for obvious reasons) to approach regional security as arenas for super power rivalry and therefore write about 'The Soviet Union and South Asia' and 'The US in the Middle East'. Post-Cold War practitioners have certainly learned the hard way how resistant regional security systems are to external transformation (the Middle East in particular). This lesson is relevant to our emerging post-post-Cold War period as well: regional dynamics are powerful and relatively separate. The first lesson thus is that the global level has to be always seen in an uneasy tension with regional dynamics, not as by definition primary just because it is 'global'.

The second importance of the regional level is that global polarity itself can only be understood by thinking global powers in relation to the(ir) regions. Especially, regions form the geopolitical foundations of the necessity to operate simultaneously with super powers and great powers.

This distinction between super power and great power has been overlooked previously due to Eurocentristic history writing and US dominated theories. The first factor, Eurocentrism, meant that the theory of polarity was built over historical experiences where one region contained all the world powers, and therefore there was only one level in the theory, where powers were placed; no distinction between great powers and super powers and no real geographical anchorage of the powers in different regions. ${ }^{6}$ The second factor, the US angle, has privileged theories with a

\footnotetext{
6 The point here is not that world security actually did unfold in this manner but (diplomatic) history writing did and especially the part of it that International Relations and Security scholars drew on. For the $16^{\text {th }}$ to $19^{\text {th }}$ Century, it was mostly the history of European great power politics and for the $20^{\text {th }}$ Century great power politics centred on Europe, even when extra-European powers played a larger role. The tendency even in IR views on North American and Russian international history in previous centuries was to treat it as mostly related to European power politics (eg. the disengagement of Spain and France in North America as derivatory of European developments; the vacillations of London in relation to the American civil war similarly, and Russia as stepping in and out of European history, not involved in other regions). Pre-Cold War history became the extended history of powers linked through the European Arena; and the Cold War was for other reasons 'flat' as well with the global level all-dominant according to IR. World History has been re-written in recent decades in ways that demonstrate a continuous interplay between regional, inter-regional and global, but this is only slowly finding its way into IR theorizing (and mostly by scholars related to the English School or Chinese IR, not American mainstream security studies).
} 
global observation point and led to a trivialization of non-global actors, which showed especially in a tendency to designate as 'regional powers' all those who did not qualify as 'super powers'. Thereby, a useful category of 'great powers' was lost. Theories made in the US tend to look at the world from the top down and not bottom up - and almost all theories were made in the US, producing a bias in conceptualizations of polarity. Most writers have used the terms as synonymous, super power simply being the terminology updated for an age of greater great powers, while the term great power either dropped out or was used on regional powers. Scholars thereby lost the opportunity to make differentiated analysis with concepts for super power, great powers and regional powers.

Thus, Buzan and I arrived at a diagnosis in 2003 called " $1+4+$ regions" = one superpower (the US), four great powers (China, Russia, EU, Japan) and regions (the 11 regional security complexes) including their regional powers. The definition of super power is 'global' in the dual sense of all kinds of power and the possibility to project it into all parts of the globe. ${ }^{7}$ A great power has influence beyond its own region, typically into neighboring regions, and it is included in considerations about global power for instance as a coalition partner that matters at the aggregate level or due to status like UNSC P5. We will get in a minute to the question what happens currently at the super power level, but probably one would argue today about who to place at the level of great powers; some will question whether Japan should move down and others whether India, Brazil or others should move up. This, however, is less important at the present stage than getting the basic structure right. The dynamics of a $1+5$ system will not be very different from a $1+4$ one. Much will change if we move to $0+\mathrm{N}$ or $2+\mathrm{N}$. (Buzan and Wæver 2003: 37-39, 455-460).

The $1+4+$ regions structure explained a lot of the dynamics in the 1990s and ' 00 s, not least the two major tensions ' 1 vs 4 ' and 'global vs regional'. The 1 vs 4 dynamic (super power vs great power) was captured even more elegantly by Samuel Huntington in his concept of uni-multipolarity (Huntington 1999) where he argued that much of the mess in world politics stemmed from one power thinking the world was unipolar and that it was the unipole and the other main powers thinking that the world both was and should be multipolar and politics conducted accordingly. A tension from the system being located between unipolarity and multipolarity was intensified by the fact that contrasting rule books were followed by those who represented one or the other near-polarity. The global-vs-regional tension was seen most clearly in the US attempt to transform the Middle East and the way the region struck back.

In Regions and Powers, emphasis was on demonstrating the value of 'regional security complex theory' (RSCT) in mapping global security through a nuanced analysis of each regional security complex. Among the strengths were that the regional map as such proved relatively stable with only a few significant changes in external boundary, internal organizing principle or mergers - this was seen as helpful because if they were fluctuating wildly they would not be helpful for

\footnotetext{
7 There are surprisingly few studies of the concept of 'super power'; see however especially Jönsson 1984.
} 
explanation, and if nothing changed that would be boring. Among other advantages were the importance of regions being either centred or balancing, and the divergence with different regions developing differently at the same time. Thus, the contribution of RSCT to a total global analysis was established. However, less emphasis was placed at that time on its contribution to capturing the global structure as such and possible changes in it. However, we did notice the importance of speculating about what would come after $1+\mathrm{N}$, and we argued already then that the most likely scenario was neither bipolarity nor multipolarity, but a world of $0+\mathrm{N}$, i.e. a world without superpowers.

This prognosis seems to have been confirmed. The way it happened was important and in accordance with the theory. Most analysts, especially in the US, have tended to assume that a change away from unipolarity can only happen through a challenger confronting the lone super power. In contrast, the theory of super and great powers allows for the possibility that the change will rather happen through abdication, through the super power shifting down to great power status. Now, leading American scholars wonder aloud "this is not how it was supposed to happen" (where "this" is the demise of the US-led liberal order). "The great threats were supposed to come from hostile revisionist powers seeking to overturn the postwar order (...) (O)rders built by great powers have come and gone-but they have usually ended in murder, not suicide" (Ikenberry 2017). And actually, this is indeed what some of us predicted some 15 years ago: that systemic change would happen through the US shifting from super to great power status. This is ultimately a question of actual power, but it shows most clearly in patterns of behavior, where the US no longer wants to perform the role of super power-and no other power wants to either. The last part of the former sentence obviously invites first of all a discussion of how to analyse Chinese policy (cf several other articles in this special issue) but the main argument at this point is that in the flat conception of polarity without distinction between super power and great power, the only possible step down would lead all the way down to 'regional power', and the only replacement for ' 1 ' seemed to be a larger number, but the option of ' 0 ' was invisible.

While the trend could be discerned and the prognosis made already in the 1990s, the actual turning point probably came around 2008. It was both military and economic, and as usual in the case of power the main mechanism was the effect of events on future expectations, because power mostly matters when considering who will be how powerful in the future. By 2008, the wars in Afghanistan and Iraq had demonstrated clearly that the US could not quickly and easily intervene and install regimes at will. This was an ironic case of the mechanism projected by the neoconservatives, only with the opposite result of the one they wanted. They assumed that a war like Iraq exactly by being unilaterally decided by the US would create a self-reinforcing perception in (especially regional) powers that this kind of punishment could follow swiftly and therefore it would be better to behave and the US would therefore not have to spend this currency in practice. The mechanism proved correct - the outcome and thereby the lesson the opposite. (This conclusion does not demand a final judgment on whether the wars in Afghanistan and Iraq will ultimately be deemed successes or not; in any case they certainly did not prove a point about US ability to swiftly and effortlessly settle matters.) The other 
mechanism where the US lost power in the eyes of others was due to the financial and economic crisis of 2007-2008, which punctuated the self-confirming standard economic model ('Washington consensus' and all that), that made states selfdiscipline into a US-centred order. After the crisis, this was turned upside down and the ability of the US to lecture others naturally met by a 'who are you to tell us' response. Politically, this corresponded with the change of presidency in the US from George W. Bush to Barack Obama, and the latter clearly tried to adjust US policy to this distribution of power-trying to continue a US position as no 1 but with less effort and especially less use of (open) force.

For a number of obvious reasons, most observers are inclined to see 2016/2017 as a dramatic rupture and emphasize the contrast between Obama and Trump. In the future, it is not impossible that we will have historians writing about the ObamaTrump period in American foreign policy. Both are trying to find ways to keep US at the centre of world politics while spending less energy and resources on actively trying to 'run' things. Obama tried to square the circle one way-through 'leading by example' and light footprint in military actions. Trump tries another route with a mixture of 'offshore balancer'-like policy of leaving the first line of defense to others and occasional demonstrative use of military force and general de-regulation to military control (Walt 2017). His systematic refusal to invest politically in institutions or relationships flashes power in the now, removes leadership and undermines superpower status. Thus, both presidents represent attempts to adjust to as US loss of relative power, while trying to preserve US primacy. Both embody American 'abdication'. Domestically, the right wing accused Obama of causing this through 'weakness' and now the left blames a US loss of position on Trump's brutality. Both sides ignore the underlying momentum.

More idiosyncratic factors relating to Donald Trump's policies and leadership style suggest a higher level of conflict due to his mercantilistic outlook on world politics and 'art of the deal' transactionalism (Trump and Schwartz 1988). In combination with disorganized domestic leadership, this points to not only a very low interest in leading and organizing internationally, but also an even lower ability to do so. Stable coalitions and cooperation cannot form around a core like that.

The next step is to unfold further the dynamics of such a 'world without superpowers'. This was not done in Regions and Powers, and Buzan and I have done this independently but mostly in synch (Wæver 2010; Buzan 2011). The main message from 'a world without superpowers' is the vacation of the global, strategic level. The good news in this is that there is little strategic rivalry about the position as super power-the bad news is that nobody feels generally responsible for world developments, and collective action is difficult to mobilize in relation to climate change, free trade agreements or civil wars with humanitarian costs.

An important feature of this system is that the different great powers are largely 'nested' in different regions. Therefore, their order of preference will typically be domestic $\rightarrow$ regional $\rightarrow$ inter-regional $\rightarrow$ global.

Even more issues will be settled regionally than in the preceding period. And the involvement of great powers in global issues will vary from issue to issue, case to case. 


\section{What is Not the Structure of the International System Today!}

The structure has received a number of alternative designations, some of which have some applicability to the current situation. However, I will here briefly indicate why they all miss out on some of the most significant features of the current system and its key dynamics and why, therefore, it is important to keep the 'regionalised world without superpowers' at the centre of the picture. The most important complementary benefits of some of the other conceptions will be noticed too.

(a) Multipolarity This designation is so obvious an alternative that most readers have probably already wondered why all this 'world without superpowers' talk is not just multipolarity? If the US departs from the position as super power and joins the group of great powers, why do these great powers not constitute then a multipolar system? Because they are not placed in the same system, not reaching each other, and not acting on the polarity of the system as such. In the classical European multipolar system, the powers were in close contact and (more importantly, given that one can argue that with growing interaction capacity, the first criteria is actually met at the global level now), the different powers in the European multipolar system had a clear sense that their status and security was dependent on shaping the overall balance of power in their favor. The powers in the present system simply do not depend to the same degree on such an overarching equation at the global level.

This distinction between classical multipolarity that was de-facto regional and the current constellation of great powers in the global system is overlooked for a number of reasons, and maybe the most important is an ambiguity inherited from the concept of balance of power. Herbert Butterfield in a classical essay (Butterfield 1966) argued that the balance of power was not an ancient institution but a modern phenomenon, because it could only be said to be in place when the participants acted on the basis of a concept of balance of power, not when they responded ad hoc to the power of various other actors and thereby got interconnected in a chain of powers. A balance of power is only operative as mechanism if the powers conceive of their system as a balance of power system-if not it might still be driven by power dynamics, but not a 'balance of power' ${ }^{8}$ Similarly, the polarity of a system has causal effects if the powers act on the assumption that it matters who are the great powers and what kind of constellation they form. A system does not become e.g. bipolar just by all powers acting on the power of all other and two of those being the most powerful and therefore their interaction becoming most consequential-it is implied in arguments about bipolarity (e.g. in Waltz 1979) that the leading states have an understanding that those two states are the most powerful and

\footnotetext{
${ }^{8}$ Often in the literature on the balance of power, this distinction between a mechanical and a reflexive balance of power conception is almost acknowledged and then sidelined because it gets over-written by a partly separate question whether a balance of power system can operate on pure self-centred calculations or it demands some kind of commitment to or support of the balance of power as an institution (a view that is rightly attributed to both Morgenthau and some English School writers) (Little 1989; Sheehan 1996; Little 2007). However, the latter and important question has unfortunately crowded out the possibly more important one about reflexivity and conceptual condensation being necessary for a system to become a balance of power system and not just a power-driven system, even if the states do not act in order to preserve it as a system, only to achieve security through it.
} 
important, both in terms of their mutual relationship and their relationship to other states. And similarly in multipolarity that states act not only in an ad hoc manner towards individual other states but actually think of this congregation of great powers forming a system where it has security importance for each state how this formation evolves. Thus, a system is only multipolar if the powers act on the assumption that it is crucial to their own security to shape the conglomerate of great powers including issues of who are in or out of this club, what relations they form to each other and how they relate to the rest of the system-or to phrase it in a slightly more causal tone: the structure itself only has independent effects if it is conceptually constituted as an object in its own right.

The current set of great powers do not form a system of this kind. Some of them might be keenly attentive to gaining (India) or preserving (Russia) the status as great power, i.e. to their own standing as club member. Also, some triangular dynamics are tightly coupled: How close will China and Russia move in (soft?) balancing of the US? Will India help the US in checking China's power at the regional level and thus relieving US from extra-regional efforts? What are the long-term prospects for the Japan-China-US constellation? However, the great powers do not follow a security calculus where the general state of the global great power constellation is decisive for their own security and therefore something they act upon at the top of their agenda. (In addition to the primary geopolitical roots of this-regional anchorage - the de-coupling is strengthened by the fact that they do not relate to general power but issue specific, and not see the club as having special status; more on the latter below.)

(B) Bipolarity (US-China) The next obvious alternative candidate for global polarity is bi-polarity. This is not the place to rehearse either the debate on US decline (bipolarity demands more decline in order to get close to parity; a world without superpowers or multipolarity are compatible with the US being above the rest but within a larger set) or the one on China's ambitions (this is covered in other articles in this issue). The main objections against this designation are as with multipolarity the lack of national security anchorage in system structure for the two and in addition the growing importance of other powers.

It is often assumed that John J. Mearsheimer's influential theory of offensive realism (Mearsheimer 2001) points towards an analysis in terms of bipolarity, because he predicts a coming conflict between the US and China (see 2nd edition; new chapter 10; 2014). However, it is quite telling that bipolarity is not actually his analysis. Despite all his positioning as being the true heir of Waltzian structural realism, Mearsheimer does actually not make system structure the main explanatory variable. His theory shares with RSCT an attempt to include more geopolitics and thereby concrete location, sea and land, specificities beyond abstract 'system and unit'. In his case, this leads to a key explanatory dynamic saying all great powers aspire for regional hegemony and given the advantages of this, they will also want to prevent others from achieving it. The US has it and wants to prevent China from getting it. There is then some confusion in the theory as to whether the source of instability in the current system (unbalanced multipolarity) stems from the regional level (China aspiring for regional hegemony) or from the global level (the US being already in an advantageous position ahead of all others). In any case, the 
explanation is not in terms of bipolarity at the global level, but in terms of regional (i.e. Asia-Pacific) dynamics having to do with intersecting aspirations by China to obtain regional hegemony and the US to present it. ${ }^{9}$ The closest this comes to an analysis in terms of bipolarity is that one might say that the reason the US wants to prevent this Chinese regional hegemony is because then the world would become bipolar.

It is easy on the basis of raw numbers in relation to economics or even military power (some way further down the line) to argue for bipolarity, but the diagnosis loses force when placed on the world map where it turns out that these two main powers are great powers rather than super powers. ${ }^{10}$

(C) Tripolarity (US, China, Russia) Amongst other Mearsheimer has argued that the system is tripolar (although I have primarily seen him do so in a youtube video from a talk in Russia, so it might have been an act of courtesy; see also Mouritzen 2017). Especially with a lot of emphasis on the military factor, one might be able to reach the conclusion that the system is tripolar, but especially if looking at underlying trends in economies and populations, it is hard to defend this position against more plausible cases for bipolarity, multipolarity or no super powers.

The next alternatives are all theories that actually do not capture the structure, but only the ensuing patterns.

(D) No One's world Charles Kupchan's elegant label (Kupchan 2012) points both to the fact that there is no longer a 'one' that can approach the world from a unipolar angle and there is no one who is willing to take responsibility for the world. Thus, it captures much the same interpretation as the one here presented, but it is less clear on what then the underlying power structure is.

(E) G-zero The interpretation by Ian Bremmer of a G-zero world goes one step further in focusing on outcome rather than structure (Bremmer and Roubini 2011). He has succinct and helpful analyses of how international institutional settings fail to produce cooperation. His explanation of this, however, is a rather vague interpretation in terms of a 'constellation' of processes and forces. This becomes even more clear in his more recent analysis "After the G-Zero" (Bremmer 2016), where Bremmer argues that we have reached the bottom of a geopolitical cycle (?!) with cooperation at a low and therefore the question now is what new order will be built. The ' $\mathrm{G}$ ' metaphor is to be taken serious here; it is an argument about what kinds of cooperative formats will emerge, but the underlying factors are so complex and many-dimensional that the cooperative format is quite independent of these structures.

(F) Going to Hell The final set of labels are 'a world adrift' (Crocker et al. 2015), 'a world in disarray' (Haass 2017) and 'the world falling apart' (Gardels 2016). These are obviously even more at the 'output' end. As others have pointed out (e.g. articles on 'the world is not falling apart'), data does not support a generally negative interpretation of the trends in wars, battle deaths or even other forms of

\footnotetext{
${ }^{9}$ Cf. Friedberg 2012; Goh 2013; Morton 2016.

${ }^{10}$ Andrew Moravcsik recently reminded us that if one treats the EU as a single unit, which is often a fair thing to do, it is on the scale of China and the US in terms of economics and even military budgets (Moravcsik 2017). In addition, the gap between the top 2-3 and the next powers is narrowing gradually.
} 
violence like genocide or homicide; on the contrary people like Pinker and Mack have argued that the trend is positive at the scale of millennia as well as zoomed in on the last century (Pinker 2012; Mack 2014). When it appears as if the trends are negative, three main explanations are: (1) there is actually an unfortunate upswing in wars and battle-deaths due to mostly the Arab Spring and especially the conflict in Syria, (2) the bias of media coverage favors negative reporting and maybe increasingly so, and-in the present context possibly most interestingly-(3) the fact that the West is less and less in control makes the world appear to Western observers more and more 'adrift' and 'falling apart'. When wars and deaths were caused by Western interventions at a time of quasi-unipolarity, this did not generate feelings of impotence and drift, only of difficult problems that were actually addressed (only badly so). Today, the world feels more out of control-to those who used to (try to) control it.

From a more structural perspective, it might even be speculated that the upturn in violence at present (especially in the Middle East) is the unfortunate combined effect of the previous and the emerging structure: the peak of unipolarity 15 years ago unleased a number of interventions that created destabilisations partly to be blamed for some of the problems in the region (including Islamic State); and the current power structure with its inability to generate joint action means that even disasters like those in Syria do not generate serious intervention.

(G) Apolarity This designation has been used by various scholars-often in debate and a few times in writing as well (Ferguson 2004; Drezner 2007). It is attractive due to its elegance and its seems to capture some of the argumentation made above. However, it is problematic because it is used variously to emphasise that there will be no pole (no superpower) or that polarity analysis has lost its relevance. The most influential promoter of the concept, Niall Ferguson, seems to see these two as two sides of the same coin, because - strangely for a historian-he buys into the idea that the only kind of power to look for is a superpower, and thus he equates 'no superpower' with total anarchy. His analysis and mine are parallel in emphasizing the deficits in cooperation and leadership likely to follow from a world without superpowers, but he (like Bremmer) ties the specific feature of the demise of the last superpower too closely into a general diagnosis of disintegrating powers. Within the IR discipline it is more common to hear the argument that 'polarity' as such is an outdated concept and when we today cannot pin a label like bipolarity or multipolarity on the system, this proves that we should no longer think in terms of polarity. This amounts to the classical methodological error or conflating a negative finding with an error; i.e. when we look for superpowers today we find none. This is an important finding not a deficiency in polarity analysis. We should therefore use this 'zero' as explanans not as absence.

This brief survey of other designations show similarities between most, but still it is important to keep a sense of structure and that the structure is decentered. The most important complementarity to this is that the global system is not fully as disconnected as this model suggests. Its quasi-multipolar and quasi-bipolar dynamics do appear irregularly, most importantly in the US-China relationship as direct security rivalry. 


\section{Great Powers and World Order}

On the basis of the above conceptualization of the power structure of the international system, the final part of the paper moves towards a concrete and constructive suggestion for what kinds of cooperation who can form about what and when. The first step is to think more principled about the role of great powers in handling global challenges. The natural starting point for this is the chapter on 'The Great Powers' in Hedley Bull's The Anarchical Society (Bull 1977). And more generally, the tradition from Ranke over Wight to Bull (and continued by contemporary English School writers) (Ranke 1916; Wight 1977, 1995).

As it is well-known, Bull's famous book examines "order in world politics" and the central part 2 looks at five institutions and mechanisms that uphold order: balance of power, international law, diplomacy, war and-the great powers. As the list demonstrates, the mechanisms are not idealized or romanticized; the list includes not only 'nice' mechanisms - more 'cynically' it includes even war.

This English School (ES) perspective is a useful corrective to the dominant perspective in liberal American IR. Much of the fear and frustration in contemporary IR over the 'threats to the liberal international order' rests on a problematic, ethnocentric analysis that assumes (1) the order was ultimately a form of 'collective good' provided by the US (out of enlightened self-interest but in everybody's interest), (2) order is favored by power imbalance rather than balance (Hegemonic Stability Theory most explicitly), and (3) there is a correlation between value consensus and order building.

Some liberal institutionalists have begun to realize how the liberal international order has created much of the force behind the rise in populism due to its de facto "hijacking" by capitalism (Colgan and Keohane 2017). Similarly, it is recognized that rising powers need to be accommodated somehow, even if this proves more painful in practice than easy declarations indicate. Still, the image of the relationship between great powers and order is thoroughly liberalist in the sense that cooperation is imagined as a free choice of the parties, not in any way 'imposed' and thus 'power' is only a facilitator in the form of the constructive power to do things, never power over others. The meaning of cooperation is furthermore presumed to be transparent because the more the parties agree in values and analysis, the better they cooperate-again excluding the possibility that cooperation can be favored by radically diverging agendas that converge only concretely, but not ultimately in their aims.

The ES tradition is different from this approach, because it assumes (1) that order is a motivating force in its own right, not only a by-product of cooperation for specific purposes; (2) efforts for order are always also power politics; and (3) cooperation is always erected on the unstable tension between 'pluralism' and 'solidarism', i.e. neither fully a projection of domestic arrangements, nor excluding these. And thereby, cooperation can be the joint product of different agendas, not only a convergence around human progress (Wæver 1998). The underlying assumption in American liberal institutionalism of a normatively homogeneous order is becoming increasingly problematic in a post-Western international system, 
and the ES has the great advantage of having had a continuous debate on the degree to which international society is dependent on underlying cultural homogeneity. ${ }^{11}$ This has prepared the ES tradition well for today assessing order-upholding institutions under new conditions (Buzan 2014). One of those institutions is 'the great powers'.

Bull's chapter on the great powers more concretely argued that great powers only become such as part of a 'club' of great powers and thus they mutually confer that status on each other-and it is a status that entails duties as well as rights. Thereby, great powers cannot be understood from the international system (structure) alone, but has to be seen in relation to international society (rules and institutions). Already at the time of writing, Bull observed that the institution of great powers was weakened, because the acceptance of status differences went against the trend during the period of decolonization and cold war competition for celebrating the principled equality of states. The main tasks of the great powers were, Bull wrote, to manage their mutual relationship and occasionally to use their joint preponderance to direct the wider society of states. The legitimacy of a special role for great powers is not strong today either. One openly contested element is 'spheres of interest' (Hast 2016), another is the room for an informal concert system running below or in parallel to formal structures like the UNSC. ${ }^{12}$

Today, the decentralized system with shifting great powers opting in issue by issue makes it harder to stabilize both dimensions of the great power institution: both the mutuality among the great powers and the joint exercise outwards become more fragile when the delineation of the group is unstable.

One of the challenges in this emerging system will be to get acceptance both inside the club and around it of partial formations taking up the role that used to belong to the club at large. Cui and Buzan argue in the most systematic and comprehensive update of ES thinking about great power management as an institution (Cui and Buzan 2016) that non-traditional security issues will be the crucial make-or-break arena for great power management in a post-unipolar, postwestern system of 'decentred globalism' that could foster such cooperation but hold mostly worrying scenarios. My analysis below similarly gives a central position to non-traditional security, but tries to sharpen the argument.

\footnotetext{
${ }^{11}$ The two key founding theorists, Wight and Bull, had slightly diverging emphasis here. Martin Wight emphasized the embeddedness of international society in the conceptual, intellectual and social evolution of specific polities and societies, in his case mostly modern Europe but including also a study of ancient Greece (Wight 1977) and this pointed further into the work of Adam Watson on different international societies throughout history (Watson 1992). Hedley Bull, in contrast, tried to theorize more abstractly, looking for institutions and mechanisms (and variation in how much international society there was, more than which one) and thus posited more of an underlying 'functional' driver (Bull 1977), although worrying about a necessary minimal cultural homogeneity that he saw as challenged with decolonization and the expansion of international society (Bull and Watson 1984)..

12 A particularly sophisticated analysis of East Asia updating ES understandings of great powers is Evelyn Goh's (Goh 2013) in terms of layers of hierarchy. However, this works for a region together with the global level in a case where the two are particularly closely linked because this is the most important region in the world, containing most great powers and most of roughly everything else. Therefore an analysis integrating some global level dynamics through the region becomes viable here in a way not dissimilar to how Europe worked vis-à-vis global analysis in previous periods, cf note 6 above.
} 
Already during the Cold War, Hedley Bull (Bull 1980) reprimanded the superpowers for de-facto being 'the great irresponsibles', and that was a time when self-interest should support leadership the most (cf Waltz's observation [1979: 128] that "The greater the relative size of a unit the more it identifies its own interest with the interest of the system"). Today, some serious global challenges call for great power responsibility, but 'great power' status works less effectively to make particular states take leadership on these.

\section{Leading for Survival, Identity and Competition}

The theoretical argument has pointed to three drivers, two of them coming out of my model, and the third from the shortcoming of this model (complementarity) —and it all adds up to a relative simple suggestion for when great powers engage in leadership on global issues under the current power structure.

The rationale for keeping to these three factors among the many possible is to stay as close as possible to classical analyses of polarity and power while acknowledging novelties today and make the necessary adjustments from within the tradition. The analysis of the current power structure-no superpowers and the great powers anchored in a regionalized system-points to an unusually low pull from system dynamics on great powers to take upon themselves leadership, because they will not be driven by their mutual positioning and jockeying for allies. In this relative vacuum, two mechanisms come to the forefront. One is new, yet in line with the tradition because it is still about security.

This first mechanism is when an issue is securitized as danger at the collective level so strongly that it motivates action even when the state also has security concerns at the state-to-state level that could speak against this (the advantage of not taking responsibility). Here, it is important to be more discerning than the otherwise helpful analysis by Cui and Buzan (2016). The terminology (particularly popular in Asia) of 'non-traditional security' tends to create an image of new issues that are second rate and still in the shadow of traditional security, but more important than they used to be. This is not enough to motivate leadership. Only when issues are thoroughly securitized as existential dangers that form survival issues of a new kind does it seem likely that they will call forth great powers who otherwise have strong motives to avoid unwelcome responsibilities.

The second mechanism comes into play also because the pull from the system is weakened. This opens the possibility that leadership can be motivated by Realpolitik motivations, but not directed at rivals or the issue as such, but at the political unit itself and its mobilization of power and stature domestically and generally in the system, i.e. by projecting a role identity around the leadership. Instead of opening wider for the multitude of domestic sources of foreign policy or general identity driven and constructivist arguments about foreign policy formation, it is analytically advantageous to privilege this particular dynamic because it is so close to the classical rationale of great powers, yet differently linked into system structure and thus able to operate in the current system. Concretely this means leadership and cooperation when one or more great powers can deploy a given 
international responsible action as part of its strengthening of the domestic polity. An example was given on this article's sixth page about the EU playing a role in international environmentalism that strengthened integration/the Commission/the EU as such, and the very act of taking leadership as building identity and institutional momentum is seen in these years in the case of China's shift "from keeping a low profile to striving for achievement" (Yan 2014).

The question now is how far we can get towards predicting patterns and degrees of cooperation by the two step procedure of (a) a basic conception of the global power structure as a 'regionalised world without superpowers', and (b) cooperation being therefore generally reluctant and insufficient, but most likely to come forth if and when one or both of two conditions are met: powers building their polity and power by the very act of showing responsible leadership or the issue can be securitized as a collective danger.

Climate change is the obvious case that seems to fulfill both of these criteria. Previous action has been constrained by concerns in especially the US and previously China that costly climate policy would entail relative economic weakening vis-a-vis the other and thus ultimately a security weakening.(Wæver 2011) This securitization of relative power competes, however, with climate change as a security threat in itself, an argument that seems to have gained more and more ground in China. In combination with the issue's status as the ultimate stewardship obligation means that taking responsibility here conveys status on the leader in case and its stateness gains increased meaningfulness domestically.

Both of these two conditions are dependent on a general image of weak system structure, i.e. the main powers are sufficiently decentered and focused on themselves and their own regions that global action will at first appear as an unwelcome 'cost' that should preferably be shifted to others. Only when a specific push comes into place will they become part of the management of a given issue.

Finally, it is necessary to include a third possible driver given that my model of the power structure does not fully match the actual state of the world and classical multi- and especially bi-polar features are present as well: the main powers do on certain issues maneuver directly vis-à-vis each other and this creates on some issues a dynamic of competitive institutionalizations, i.e. leadership for 'cooperation' with a large element of rivalling coalitions as with the different schemes for regional Asia-Pacific economic integration. In contrast to previous periods, this kind of dynamic is not consistent and pervasive in the current system, so it can be expected to manifest itself most strongly on those issues that are most import to immediate power rivalry.

If we use this model to look at a range of the issues that appear as possible cases of stewardship by the great powers, a quick check-through seems to confirm the rough model:

- Climate change is as mentioned a case where the securitization of global existential danger is competing with classical national security logic, with the former driving involvement and the latter holding it back (Wæver 2011, 2017). In combination with the identity-polity gains from a climate role, a dual leadership by the EU and China in this area seems more than a short-term saving 
of the moment. It is important in this way to check the conditions for leadership because today there is a widespread tendency to read the ability of the EU and China to save climate cooperation as announcing an era where EU and China will lead generally. This is not likely-there are very specific reasons why it is possible in this domain. The underlying interaction capacity creating a kind of shared-fate challenge that becomes securitized more and more dramatically and provides domestic legitimacy as a rationale for politics.

- International trade agreements does not hold a strong potential for either identity-polity dynamics nor for collective securitization, and thus the logic of competitive rivalling formats are likely to continue. Thus, we see attempted leadership here, but most often up against rivalling leadership-sometimes annulling each other, sometimes creating more cooperation but in partly contradictory formats.

- The civil war in Syria has mostly generated non-leadership. There is some possibility that ultimately Russia and US will lead together with the main regional powers in the Middle East. The case fulfills none of the criteria, so this fits well.

- Some technology developments like cyber security are so closely entwined with power structures of global reach and has so far experienced only weak securitization of the collective dangers, and are therefore likely to move very slowly internationally.

- Other technologies like artificial intelligence with the potential of machine superintelligence pose existential dangers to mankind that are beginning to be appreciated. At the same time these technologies also hold the potential of such large scale acceleration of the power of the leading state in the field that it would transcend the current geo-technological distance in the system and make global power more relevant than so far. Thus, these technologies are the strongest case of simultaneously very strong forces for and against cooperation. In this case, cooperation would have to be centred on the US and China as the two most likely locations of such breakthroughs. More concretely, the two actors likely to lead the race for machine super-intelligence will be Google and the Chinese state, making for an even more complex constellation for cooperation and regulation (Wæver 2017).

- Military regimes of restraint and confidence building are likely to be regional and organized about the given centres of potential escalation (cf the Morton article in this issue). Global regimes are unlikely, because no obvious national benefits from projection of identity are in the offering and nor do the most dangerous issues point to global causes, rather regional ones. Here, cooperation has to be among the main rivals, not the best friends.

- The growing violence potential of yet smaller units that comes with the growing capacities of humans technologically creates a dual spectre of terrorism and surveillance, of violence seeping into societal normality or state control becoming tight to an unprecedented degree. This challenge is mostly handled at the domestic level with different balances being struck, but de facto structures of cooperation are forming among states, only not publicized very strongly. In this area, the pattern of international cooperation is one where most states cooperate 
to some extent, but some clusters are forming of particularly intense cooperation especially around the US and China respectively. These structures could become among the most important in the future because they will grow increasingly closely connected to socio-political control structures domestically. Whether these become driven by competitive institutionalizations, informal transnationalism or formalized cooperation is a major issue to assess and articulate at present.

\section{Conclusion}

The international system is not multipolar, nor is it bipolar or unipolar. This is not because polarity has become outdated, and power so diffuse that we should forget about polarity analysis. Only we need to get it right. This means to operate with the analytical triad of superpowers (with the powerful number zero being at least the proper count very soon), great powers and regions. In a world of no superpowers and with the great powers nested in different regions and with more pressing agendas than global issues, it is likely that power rivalry as a self-propelling dynamic of its own will be less powerful than it has been in most chapters of history. The main price to pay for this gain is a difficulty in generating global cooperation on joint challenges, which is a quite unfortunate at a time when some global dangers are becoming quite serious due to the gradual increase in human interaction capacity with dramatic effects on both the relationship between humans and planet (climate change, biodiversity) and on the destruction potential of humans (micro scale and macro scale; terror and AI). At this stage, it is unhelpful to examine cooperation in the moralizing format usually cultivated by IR. These form-follows-function visions of adapting political organization to the socio-economic demands carry a political naivety that often ends up hiding built-in political agendas of those who lead the cooperative schemes. It is therefore more productive to turn the analysis upside down and start from the assumption that cooperation will not happen, that states will be inward looking until compelled to the opposite by agendas strong enough to operate nationally - and this can most easily happen because a leadership role in a given area holds the potential of strengthening the state in case domestically or because the area contains dangers sufficiently large to make cooperation appear as not just nice but necessary. Unfortunately, the latter securitizing route might be the most realistic one on some major technology centred challenges on the agenda. This is not ideal because securitization as the route to cooperation will reinforce the undemocratic nature of action that is already implied in structuring cooperation around ad-hoc coalitions of great powers. But today, the most likely alternative is inaction-the structurally stimulated first choice.

Acknowledgements An earlier version of this paper was presented at Fudan University in Shanghai on 19 June 2017 at a conference co-organised by Fudan and University of Copenhagen on 'International Leadership in the New World Order'. I appreciate very helpful comments from the other participants, many of whom appear in this issue. 


\section{References}

Acharya, Amitav. 2014. The end of American world order, Cambridge: Polity.

Bramsen, Isabel, Poul Poder, and Ole Wæver (eds.). 2018. Addressing international conflict: dynamics of escalation, continuation \& resolution. London: Routledge.

Bremmer, Ian (2016) After the G-zero: overcoming fragmentation. Eurasia Group, New York. https:// www.eurasiagroup.net/siteFiles/Issues/After_The_G_Zero_.pdf. Accessed 27 Oct 2017.

Bremmer, Ian, and Nouriel Roubini. 2011. A G-Zero world. Foreign Affairs 90(2):2-7.

Bull, Hedley. 1977. The anarchical society. A study of order in world politics. New York: Columbia University Press.

Bull, Hedley. 1980. The great irresponsibles? The United States, the Soviet Union, and world order. International Journal 35: 437-447.

Bull, Hedley, and Adam Watson (eds). 1984. The expansion of international society. Oxford: Clarendon Press.

Butterfield, Herbert. 1966. The balance of power. In Diplomatic investigations: essays in the theory of international politics, ed. H. Butterfield, and M. Wight, 132-148. London: Allen and Unwin.

Buzan, Barry. 2011. A world order without superpowers: decentred globalism. International Relations 25 (1): $3-25$.

Buzan, Barry. 2014. An introduction to the English school of international relations: the societal approach. Cambridge: Polity.

Buzan, Barry, Richard Little, and Charles Jones. 1993. The logic of anarchy: neorealism to structural realism. New York: Columbia University Press.

Buzan, Barry, and Ole Wæver. 2003. Regions and powers: the structure of international security. Cambrdige: Cambridge University Press.

Buzan, Barry, and Ole Wæver. 2009. Macrosecuritisation and security constellations: reconsidering scale in securitisation theory. Review of International Studies 35: 253-276.

Colgan, Jeff D., and Robert O. Keohane. 2017. The liberal order is rigged. Foreign Affairs 96: 36-44.

Crocker, Chester A., Fen Osler Hampson, and Pamela Aall (eds.). 2015. Managing conflict in a world adrift. Washington, DC: United States Institute of Peace.

Cui, Shunji and Barry Buzan. 2016. Great power management in international society. The Chinese Journal of International Politics 9(2):181-210

Deudney, Daniel. 2006. Bounding power: republican security theory from the polis to the global village. Princeton: Princeton University Press.

Drezner, Daniel W. 2007. Are we moving towards apolarity? Foreign Policy. https://foreignpolicy.com/ 2007/01/31/are-we-moving-towards-apolarity/. Accessed 27 Oct 2017.

Ferguson, Niall. 2004. The end of power. Wall Street Journal (June 21).

Friedberg, Aaron L. 2012. A contest for supremacy: China, America, and the struggle for mastery in Asia. London: W. W. Norton \& Company.

Gardels, Nathan. 2016. Why the world is falling apart. Huffington Post. http://www.huffingtonpost.com/ nathan-gardels/world-falling-apart_b_9553982.html. Accessed 27 Oct 2017.

Goh, Evelyn. 2013. The struggle for order: hegemony, hierarchy, and transition in post-Cold War East Asia. Oxford: Oxford University Press.

Goldmann, Kjell. 1974. Tension and détente in bipolar Europe. Lund: Esselte Studium.

Haass, Richard. 2017. A world in disarray, American foreign policy and the crisis of the old order. New York: Penguin Press.

Hast, Susanna. 2016. Spheres of influence in international relations: history, theory and politics. London: Routledge.

Huntington, Samuel P. 1999. The lonely superpower. Foreign Affairs 78: 35-49.

Ikenberry, G.John. 2017. The plot against American foreign policy. Foreign Affairs 96 (3): 2-9.

Jachtenfuchs, Markus. 1994. International policy-making as a learning process: the European Community and the greenhouse effect. PhD Thesis. Florence: European University Institute.

Jönsson, Christer. 1984. Superpower: comparing American and Soviet foreign policy. London: Frances Pinter.

Kissinger, Henry A. 1957. A world restored: Castlereagh, Metternich and the restoration of peace, 1812-1822. Boston: Houghton Mifflin Company.

Kupchan, Charles A. 2012. No one's world: the west, the rising rest, and the coming global turn. Oxford: Oxford University Press. 
Latour, Bruno. 2013. An inquiry into modes of existence: an anthropology of the moderns. Translated by Catherine Porter. Cambridge: Harvard University Press.

Little, Richard. 1989. Deconstructing the balance of power: two traditions of thought. Review of International Studies 15: 87-101.

Little, Richard. 2007. The balance of power in international relations: metaphors, myths and models. Cambridge: Cambridge University Press.

Luhmann, Niklas. 1990. Die Wissenschaft der Gesellschaft. 1. Frankfurt am Main: Suhrkamp Verlag.

Mack, Andrew. 2014. Human security report 2013: the decline in global violence-evidence, explanation, and contestation. Vancouver: Human Security Press.

Mearsheimer, John J. 2001. The tragedy of great power politics. New York: Norton.

Moravcsik, Andrew. 2017. Europe is still a superpower. Foreign Policy, https://foreignpolicy.com/2017/ 04/13/europe-is-still-a-superpower/. Accessed 27 Oct 2017.

Morgenthau, Hans J. 1948. Politics among nations: the struggle for power and peace. New York: A.A. Knopf.

Morton, Katherine. 2016. China's ambition in the South China Sea: is a legitimate maritime order possible? International Affairs 92: 909-940.

Mouritzen, Hans. 2017. Small states and finlandisation in the age of Trump. Survival 59: 67-84.

Niebuhr, Reinhold. 1932. Moral man and immoral society: a study in ethics and politics. New York: Charles Scribner's Sons.

Pinker, Steven. 2012. The better angels of our nature: why violence has declined, Reprint ed. New York: Penguin Books.

Ranke, Leopold von. 1916. Die Grossen Mächte. Re-published Leipzig: Insel-Verlag zu Leipzig (originally Historisch-Politische Zeitschrift 1833).

Ruggie, John G. 1983. Continuity and transformation in the world polity: toward a neo-realist synthesis. World Politics 35: 261-285.

Sheehan, Michael. 1996. The balance of power. London: Routledge.

Tang, Shiping. 2013. The social evolution of international politics. Oxford: Oxford University Press.

Trump, Donald J. with Tony Schwartz. 1988. Trump: the art of the deal. New York: Randon House.

Wæver, Ole. 1992. Introduktion til studiet af international politik (A text book for teaching international relations at the University Level). Copenhagen: Politiske Studier.

Wæver, Ole. 1998. Four meanings of International Society: a trans-Atlantic dialogue. In International society and the development of international relations theory, ed. B.A. Roberson, 80-144. London: Pinter.

Wæver, Ole. 2010. Magtesløshed og Mangfoldighed: Verden efter Vestens Vælde (Powerlessness and diversity). Udenrigs 65: 6-24.

Wæver, Ole. 2011. Geopolitics and governance. In Climate change: global risks, challenges and decisions, ed. Katherine Richardson, Will Steffen, and Diana Liverman, 344-387. Cambridge: Cambridge University Press.

Wæver, Ole. 2017. The international politics of dramatically dangerous technologies. Paper presented at the annual meeting of $4 \mathrm{~S}$ (Society for Social Studies of Science), August-September in Boston.

Walt, Stephen M. 2017. Policy series: “The Donald versus 'The Blob.” ISSF. February 14; https:// issforum.org/roundtables/policy/1-5n-blob. Accessed 27 Oct 2017.

Waltz, Kenneth N. 1979. Theory of international politics. New York: Random House.

Watson, Adam. 1992. The evolution of international society. London: Routledge.

Wendt, Alexander. 1992. Anarchy is what states make of it: the social construction of power politics. International Organization 46: 391-425.

Wight, Martin. 1977. Systems of states. Leicester: Leicester University Press.

Wight, Martin. 1995. Power politics. Leicester: Leicester University Press.

Yan, Xuetong. 2013. For a new bipolarity: China and Russia vs. America. New Perspectives Quarterly 30: $12-15$.

Yan, Xuetong. 2011. International leadership and norm evolution. The Chinese Journal of International Politics 4: 233-264.

Yan, Xuetong. 2014. From keeping a low profile to striving for achievement. The Chinese Journal of International Politics 7: 153-184.

Yan, Xuetong, Daniel Bell, and Zhe Sun. 2011. Ancient Chinese thought, modern Chinese power. Princeton: Princeton University Press. 
Ole Wæver is Professor of International Relations at the Department of Political Science, University of Copenhagen, and Director of the Center for Resolution of International Conflicts. He was the founder and from 2008 to 2013 the director of Centre for Advanced Security Theory. Among his main books are Security: A New Framework for Analysis (with Barry Buzan and Jaap de Wilde, Lynne Rienner 1988, Chinese 2002, Czech 2006); Regions and Powers: The Structure of International Security (with Barry Buzan, Cambridge University Press 2003; Chinese and Persian translations 2009); International Relations Scholarship Around the World (ed with Arlene B. Tickner, Routledge 2009); Climate change: Global Risks, Challenges and Decisions (with Katherine Richardson et al. Cambridge University Press 2011). 